\title{
Fatal Lactic Acidosis in Infancy with a Defect of Complex III of the Respiratory Chain
}

\author{
MARK A. BIRCH-MACHIN, ISOBEL M. SHEPHERD, NICHOLAS J. WATMOUGH, \\ H. STANLEY A. SHERRATT, KIM BARTLETT, VICTOR M. DARLEY-USMAR, \\ DAVID W. A. MILLIGAN, ROBERT J. WELCH, ALBERT AYNSLEY-GREEN, AND \\ DOUGLASS M. TURNBULL \\ Human Metabolism Research Centre, Departments of Neurology [M.A.B.-M., I.M.S., N.J.W., D.M.T.], Child \\ Health [K.B., D.W.A.M., R.J.W., A.A.-G.], Pharmacological Sciences /H.S.A.S.], University of Newcastle upon \\ Tyne, Newcastle upon Tyne, NE2 4HH U.K., and the Wellcome Research Laboratories [V.M.D.-U.], \\ Beckenham, Kent, BR3 3BS, U.K.
}

\begin{abstract}
We report our studies on the metabolic defects which caused a newborn infant to present with a severe lactic acidemia $(25 \mathrm{mM})$ and to die on the $3 \mathrm{rd} \mathrm{d}$ after birth despite intensive supportive measures. The mitochondrial fractions prepared from skeletal muscle and liver oxidised $\mathrm{NAD}^{+}$-linked substrates and succinate slowly. Spectrophotometric assays for complexes I, II, and III of the respiratory chain demonstrate a specific defect of complex III in the skeletal muscle and liver mitochondrial fractions. The concentrations of cytochrome $b$ were $75 \%$ lower in the skeletal muscle and heart mitochondria than in control preparations. The amount of non-heme iron sulphur protein of complex III was low in skeletal muscle, liver, and heart. This case differs from previous reports of complex III deficiency in three respects: the patient presented in the neonatal period, the defect was expressed in several tissues, and it was fatal. (Pediatr Res 25: 553-559, 1989)
\end{abstract}

\section{Abbreviations}

DNP, dinitrophenol

$R C R$, respiratory control ratio

UQ, ubiquinone-1

$\mathrm{UQ}_{1} \mathbf{H}_{2}$, ubiqinol-1

Lactic acidosis is an important clinical problem which can be caused by one of several biochemical lesions (1) including inborn errors of one or more of the complexes of the mitochondrial respiratory chain (2). In patients with the latter abnormality, the impaired flux of electrons along the respiratory chain to oxygen limits the oxidation of pyruvate. This is converted to lactate so maintaining the cytosolic $\mathrm{NADH} / \mathrm{NAD}^{+}$ratio and allowing glycolysis to continue. We describe the clinical and biochemical investigations of a neonate who died with severe lactic acidosis due to a defect of complex III of the respiratory chain.

The respiratory chain is divided into four complexes: complex I (NADH-ubiquinone reductase), complex II (succinate-ubiquinone reductase), complex III (ubiquinol-cytochrome $c$ reductase), and complex IV (cytochrome $c$ oxidase). These complexes, each of which contains several polypeptide subunits span the

Received August 2, 1988; accepted December 14, 1988

Correspondence Dr. D. M. Turnbull, Department of Neurology, Royal Victoria Infirmary, Newcastle upon Tyne, NE1 2LP U.K.

Supported by the Medical Research Council and the Muscular Dystrophy Group of Great Britain. mitochondrial inner membrane. The respiratory chain transfers electrons from reduced cofactors to molecular oxygen. The passage of electrons along the respiratory chain is used to generate a proton gradient across the inner mitochondrial membrane which is used for the synthesis of ATP (3). Complex III consists of 11 subunits; core proteins 1 and 2, a nonhem FeS centre (nFeS, Rieske protein), cytochrome $b$, cytochrome $c_{1}$ and six additional peptides (4). Cytochrome $b$ has 2 iron-porphyrin prosthetic groups with characteristic absorption spectra and oxidation reduction potentials (cytochrome $b_{i}\left[b_{562}\right]$ and cytochrome $b_{\mathrm{o}}\left[\mathrm{b}_{566}\right]$ ) bound to a single protein. Ten peptides of complex III are coded for by nuclear DNA, synthesized on cytoplasmic ribosomes and imported into the mitochondrial inner membrane; only the apoprotein of cytochrome $b$ is coded for and synthesized by the mitochondria.

\section{CASE REPORT}

The patient was male, the 3rd baby born to healthy, unrelated parents. The pregnancy was normal until the 3 rd trimester when fetal growth was noted to be slow. Because of this, delivery was induced at $38 \mathrm{wk}$ of gestation. During labor, there was no fetal distress, and the baby was delivered vaginally. The two previous pregnancies were uneventful and the siblings are alive and well. There is no family history of neurologic or metabolic disease.

The baby's wt $(2020 \mathrm{~g})$ was below the 3 rd percentile for gestational age, and there was wasting of the buttocks and thighs compatible with intrauterine growth retardation. The circumference of his head was $30.5 \mathrm{~cm}$, and his anterior fontanelle was normotensive. He was irritable but otherwise neurologically normal. He had a mass palpable in the left hypochondrium due to a polycystic kidney.

At four h of age, the baby started to hyperventilate and became hypotonic. He was hypoglycemic (blood glucose $0.7 \mathrm{mM}$ ) with a severe lactic acidosis (blood lactate concentration $25 \mathrm{mM}$; pyruvate $185 \mu \mathrm{M}$; bicarbonate $6 \mathrm{mM}$; arterial blood $\mathrm{pH}$ was 7.13). There was generalized aminoaciduria compatible with renal tubular dysfunction. Aminoaciduria has previously been described in cytochrome $c$ oxidase deficiency (5).

He was given a bolus of dextrose intravenously $\left(0.2 \mathrm{~g} \cdot \mathrm{kg}^{-1}\right)$ and was started on a continous infusion of $10 \%$ dextrose at a rate of $6 \mathrm{mg}^{-1} \cdot \mathrm{kg}^{-1} \cdot \mathrm{min}$. His blood glucose concentration returned to normal, and he subsequently remained normoglycemic. A bicarbonate infusion was given, but this failed to improve his condition and acidosis. Peritoneal dialysis was then commenced, and his blood pH increased to 7.31, and his blood lactate concentration fell to $18.5 \mathrm{mM}$. He was given thiamine, riboflavin, and biotin ( $100 \mathrm{mg}, 100 \mathrm{mg}$, and $30 \mathrm{mg}$, respectively). 
The patient remained conscious with normal tone, although he was iritable on handling. At $36 \mathrm{~h}$ of age he developed dystonic posturing, seizures, and coma and died at $53 \mathrm{~h}$ despite peritoneal dialysis and vitamin therapy. Consent for an urgent postmortem examination was given and tissues (skeletal muscle, liver, heart, and kidney) were removed within one $h$ of death and placed in ice-cold isolation media (see below). Mitochondrial fractions were prepared within 2-4 h of removal of the tissues.

\section{MATERIALS AND METHODS}

Materials. $\mathrm{UQ}_{\perp}$ was a gift from Takeda Chemical Industries, Osaka, Japan. Nitrocellulose filters $(0.45-\mu \mathrm{m}$ pore size) were obtained from Anderman and Co., London, UK. Other biochemicals were obtained from the Sigma Chemical Co. (St. Louis, $\mathrm{MO}$ ) or from Boehringer Corp., (Indianapolis, IN).

Cytochemistry. Muscle obtained by biopsy was frozen in dichlorodifluoromethane (Arcton 12, ICI) and cooled to $-150^{\circ} \mathrm{C}$ in liquid nitrogen. Routine cytochemical screening using frozen sections (6) included demonstration of cytochrome $c$ oxidase activity (7).

Preparation of mitochondrial fractions. Skeletal muscle mitochondrial fractions were prepared from $0.4-2.0 \mathrm{~g}$ of quadriceps from infant and adult controls (patients with no evidence of neuromuscular pathology) and from $5 \mathrm{~g}$ of the patient's muscle as described by Watmough et al., (8). We were unable to obtain human heart suitable for oxidative studies or for assay of the individual complexes. The liver and kidney mitochondrial fractions were prepared as described by Gatley and Sherratt (9) except that the medium used was $250-\mathrm{mM}$-sucrose, $10-\mathrm{mM}$ Hepes, 1-mM EGTA, pH 7.2. Defatted BSA $\left(5 \mathrm{mg} \cdot \mathrm{mL}^{-1}\right)$ was added during homogenization. No human kidney controls were available; the control liver samples were obtained from children or adults undergoing diagnostic laparotomy who were found to have no detectable metabolic disease. Protein was determined by a modified Lowry method (10).

Determination of mitochondrial oxidations. Substrate oxidations by mitochondrial fractions $\left(0.2-0.4 \mathrm{mg} \cdot \mathrm{ml}^{-1}\right.$ final assay protein concentration) were recorded spectrophotometrically using an Hitachi 557 dual-wavelength spectrophotometer by following the reduction of ferricyanide at $420 \mathrm{~nm}$ with $475 \mathrm{~nm}$ as a reference wavelength (11). Oxygen consumption was measured polarographically at $30^{\circ} \mathrm{C}$ in a final vol of $750 \mu \mathrm{l}$; RCRs and $\mathrm{ADP} / \mathrm{O}$ ratios were calculated as described by Sherratt et al. (10).

Determination of cytochrome redox spectra. The low temperature reduced minus-oxidized spectra of mitochondrial fractions after reduction with succinate, and after further reduction with dithionite, were recorded (10). The wavelengths and extinction coefficients quoted by Bookelman et al. (12) and an intensification factor of 7 for the medium (13) was used to calculate the cytochrome concentrations.

Spectrophotometric assay of individual respiratory chain complexes. Before determining the activity of the individual complexes, the mitochondrial membranes were disrupted by freeze thawing three times. A total of $0.6 \mathrm{mg}$ of mitochondrial protein was required to determine the activity of complexes I-IV.

Complex I (NADH ubiquinone reductase). A modification of the method described by Fischer (14) was used. The oxidation of NADH by complex I was recorded using the ubiquinone analogue $\mathrm{UQ}_{1}$ as the electron acceptor. The assay medium (35$\mathrm{mM} \mathrm{KH} \mathrm{PO}_{4}, 5-\mathrm{mM} \mathrm{MgCl}_{2}, 2-\mathrm{mM} \mathrm{KCN}, \mathrm{pH} 7.2$ ) was supplemented with defatted BSA $\left(2.5 \mathrm{mg} \cdot \mathrm{mL}^{-1}\right)$, antimycin $(2 \mu \mathrm{g}$. $\left.\mathrm{mL}^{-1}\right), 65-\mu \mathrm{M} \mathrm{UQ}_{1}$ and $0.13-\mathrm{mM}$ NADH in a final vol of 1.0 $\mathrm{mL}$. The enzyme activity was determined at $30^{\circ} \mathrm{C}$ and the reaction started with $60-90 \mu \mathrm{g}$ mitochondrial protein. The decrease in absorption due to NADH oxidation was measured at $340 \mathrm{~nm}$ with $425 \mathrm{~nm}$ as a reference wavelength. As NADH cytochrome $b_{5}$ reductase in the outer mitochondrial membrane also oxidizes NADH (15), complex I activity was calculated from the difference in rate before and after the addition of rotenone $\left(2 \mu \mathrm{g} \cdot \mathrm{mL}^{-1}\right)$, a specific inhibitor of complex I.

Complex II (succinate ubiquinone reductase). The oxidation of succinate by complex II was recorded with $\mathrm{UQ}_{1}$ as an electron acceptor. The assay medium (35- $\mathrm{mM} \mathrm{KH}_{2} \mathrm{PO}_{4}, 5-\mathrm{mM} \mathrm{MgCl}_{2}$, 2-mM KCN, pH 7.2) was supplemented with $65-\mu \mathrm{M} \mathrm{UQ}_{1}$, antimycin $\left(2 \mu \mathrm{g} \cdot \mathrm{mL}^{-1}\right)$, rotenone $\left(2 \mu \mathrm{g} \cdot \mathrm{mL}^{-1}\right)$, and $60-90 \mu \mathrm{g}$ of mitochondrial protein in a final vol of $1.0 \mathrm{~mL}$ at $30^{\circ} \mathrm{C}$. The reaction was started by addition of $8-\mathrm{mM}$ succinate and the decrease in absorbance due to the reduction of $\mathrm{UQ}_{1}$ to ubiquinol followed at $280 \mathrm{~nm}$ with $465 \mathrm{~nm}$ as a reference wavelength. A reduced minus-oxidized extinction coefficient for $\mathrm{UQ}_{1}$ of 13 $\mathrm{mM} \cdot{ }^{-1} \mathrm{~cm}^{-1}$ was used to calculate the rates (16). Complex II activity was inhibited $65-85 \%$ by $50-\mu \mathrm{M}$-thenoyltrifluoroacetone.

Complex III (ubiquinol-cytochrome c reductase). This procedure is a modification of the method of Nelson and Gellerfors (17). The oxidation of $\mathrm{UQ}_{1} \mathrm{H}_{2}$ by complex III was determined using cytochrome $c$ (III) as the electron acceptor. To prepare $\mathrm{UQ}_{1} \mathrm{H}_{2}, 7-\mathrm{mM} \mathrm{UQ}_{1}$ in ethanol was reduced with excess solid sodium borohydride; reduction was assumed to be complete after a few minutes. The addition of $12 \mu \mathrm{L}$ of $3-\mathrm{M} \mathrm{HCl}$ (final concentration $0.1 \mathrm{M}$ ) stabilizes the $\mathrm{UQ}_{1} \mathrm{H}_{2}$ and destroys the residual borohydride. Insoluble material was removed by centrifugation at $12000 \times g_{\text {av }}$ for $4 \mathrm{~min}$. The $\mathrm{UQ}_{1} \mathrm{H}_{2}$ can be stored in the dark for up to $24 \mathrm{~h}$. Before each experiment, the characteristic UV spectra of $\mathrm{UQ}_{1}$ and $\mathrm{UQ}_{1} \mathrm{H}_{2}$ were determined to confirm that none of the ubiquinol had been oxidized. The assay medium (35-mM KH $\mathrm{KHO}_{4}, 5-\mathrm{mM} \mathrm{MgCl}_{2}, 2-\mathrm{mM} \mathrm{KCN}$, pH 7.2) was supplemented with defatted BSA $\left(2.5 \mathrm{mg} \cdot \mathrm{mL}^{-1}\right), 15-\mu \mathrm{M}$-cytochrome $c$ (III) and rotenone $\left(2 \mu \mathrm{g} \cdot \mathrm{mL}^{-1}\right)$ in a final vol of $1.0 \mathrm{~mL}$ at $30^{\circ} \mathrm{C}$. UQ ${ }_{1} \mathrm{H}_{2}(15 \mathrm{nmol})$ was added, and the nonenzymatic reduction of cytochrome $c$ (III) was recorded $(550 \mathrm{~nm}$ with 580 $\mathrm{nm}$ as the reference wavelength) for $1 \mathrm{~min}$. The reaction was started with 15-30 $\mu \mathrm{g}$ of mitochondrial protein, and the enzyme activity is expressed as an apparent first order rate constant after the remaining cytochrome $c$ was reduced by a few grains of ascorbic acid. Antimycin inhibited this activity by $95 \%$.

Complex IV (cytochrome c oxidase). Cytochrome oxidase activity was determined spectrophotometrically as described by Smith (18) using cytochrome $c$ (II) as substrate and is expressed as an apparent first order rate constant with respect to cytochrome $c$ (II) concentration. A final concentration of mitochondrial protein of $15-30 \mu \mathrm{g} \cdot \mathrm{mL}^{-1}$ was used in the assay.

Duroquinol-ubiquinone transhydrogenase activity. The assay is based on the studies of Boveris et al. (19). The transhydrogenase reaction involves reduction of cytochrome $b_{\mathrm{i}}$ by duroquinol, which then reduces ubiquinone. The assay medium contained in a total vol of $1.0 \mathrm{~mL}$ at $30^{\circ} \mathrm{C}: 100-\mathrm{mM} \mathrm{KCl}, 1-\mathrm{mM}$ EGTA, 2$\mathrm{mM} \mathrm{KCN}, 50-\mathrm{mM}$ Hepes ( $\mathrm{pH} 7.0$ ), 0.1-mM duroquinol (prepared in the same way as $\mathrm{UQ}_{1} \mathrm{H}_{2}$ ) and $0.2-0.4 \mathrm{mg}$ of mitochondrial protein. The reaction was started with $8 \mu \mathrm{M} \mathrm{UQ}_{1}$ and the decrease in absorbance was followed using the wavelength pair $284-305 \mathrm{~nm}$. Sp act was defined as an apparent first order rate constant. This includes both the enzyme catalyzed rate, which was inhibited by antimycin, and a spontaneous chemical reaction. It was confirmed that enzyme activity at cytochrome $b_{\mathrm{i}}$ was unaffected by myxothiazol $\left(2 \mu \mathrm{g} \cdot \mathrm{mL}^{-1}\right)$, which inhibits electron transport at cytochrome $b_{o}(20)$.

Immunoblot analysis of peptide subunits of complex III. Mitochondrial fractions were solubilized by incubation with $8-\mathrm{M}$ urea, $2 \%$ (vol/vol) mercaptoethanol, $5 \%(\mathrm{wt} / \mathrm{vol}) \mathrm{SDS}$ at $30^{\circ} \mathrm{C}$ for $1 \mathrm{~h}$. Peptides were separated by SDS-PAGE as described by Fuller et al. (21); both the stacking gel (5\% polyacrylamide) and the separating gel contained 6-M urea. Antisera were raised in rabbits against holobeef heart complex III and subunits of the complex (22). A $15 \%$ separating gel was used for immunoblotting using antisera to the holocomplex III and the nFeS protein and a $10 \%$ separating gel for the core proteins. The proteins were transferred electrophoretically from the gel to a nitrocellulose 
filter as described by Towbin et al. (23) with the addition of $1 \%$ SDS to the transfer buffer. Immunoreactive peptides were visualised using the immunoperoxidase method with 4-chloro-1naphthol as substrate (24).

\section{RESULTS}

Cytochemistry. Skeletal muscle appeared histologically and histochemically normal for a child of this age. Deficiency of the respiratory chain including complex III deficiency usually causes morphologic changes, notably the accumulation of abnormal mitochondria. However, several patients have been described without such changes (25), and it should be emphasized that normal muscle morphology does not exclude a respiratory chain defect. The histologic demonstration of cytochrome $c$ oxidase activity excluded the benign form of cytochrome $c$ oxidase deficiency (2)

Substrate oxidations. Oxidations by mitochondrial fractions were measured within $8 \mathrm{~h}$ of death. The maximum rates of succinate and of glutamate plus malate oxidation by muscle mitochondria from the patient, measured using ferricyanide as acceptor, were about $20-30 \%$ of those from mitochondrial fractions from children and adults (Table I). We have no control data from normal human neonates. Cardiac mitochondria were tightly coupled with an unimpaired capacity for oxidative phosphorylation (not shown). Kidney mitochondria were also coupled with an RCR of 3.5 and ADP/O ratio of 3.4 with glutamate plus malate as substrate. Muscle and liver mitochondria were poorly coupled (RCR 1.5), although it is not known if this was due to postmortem changes in the tissue. The maximum rates of oxygen uptake recorded (ng atoms $\mathrm{O} \cdot \mathrm{min}^{-1} \cdot \mathrm{mg}$ protein ${ }^{-1}$ ) were: skeletal muscle; succinate 64 , glutamate plus malate 49 (controls [glutamate plus malate], $116 \pm 31 ; n=4$ ), heart; glutamate plus malate 146, liver; succinate 86 , glutamate plus malate 76 , kidney; succinate 54 , glutamate plus malate, 25 .

Cytochrome concentration. Reduced minus oxidized spectra were determined for skeletal muscle mitochondrial fractions (Fig. 1; Table 2) and cardiac muscle mitochondrial fractions (Table 2). The cytochrome $a a_{3}$ and cytochrome $b$ concentrations determined both after reduction with succinate or dithionite were respectively about $50 \%$ and $75 \%$ lower than in normal mitochondria (Table 2). The lower concentration of cytochrome $b$ was confirmed from the decrease in absorption at $428 \mathrm{~nm}$ in the Soret regions of the spectra (not shown). The absorption due to cytochrome $\mathrm{b}$ in skeletal muscle and heart mitochondria after reduction with succinate was approximately doubled by further reduction with dithionite with a peak shift from $562 \mathrm{~nm}$ to 566 $\mathrm{nm}$ (Fig. 1) showing the presence of both cytochromes $b_{\mathrm{o}}$ and $b_{\mathrm{i}}$. When the ratio of cytochrome $a a_{3}$ to cytochrome $c$ was calculated, it was found to be close to control values, whereas the cytochrome $b$ to either cytochrome $a a_{3}$ or cytochrome $c$ was only

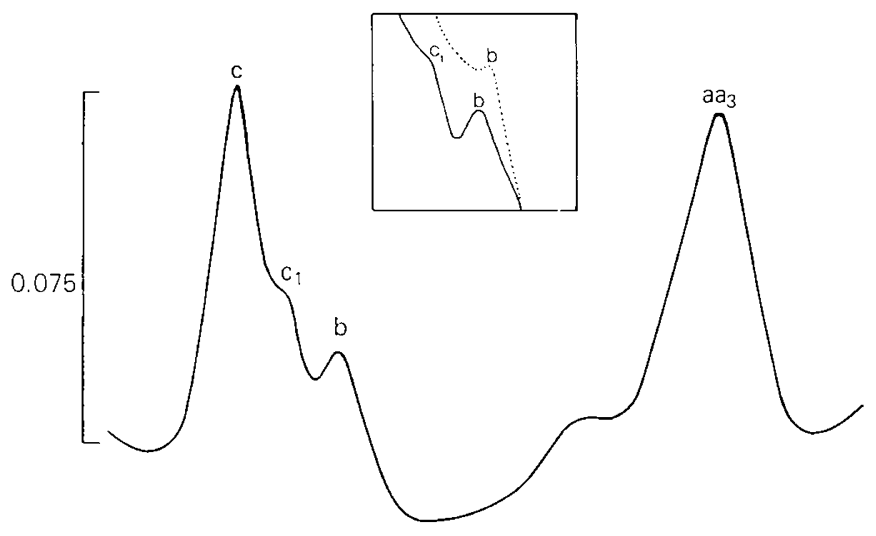

A
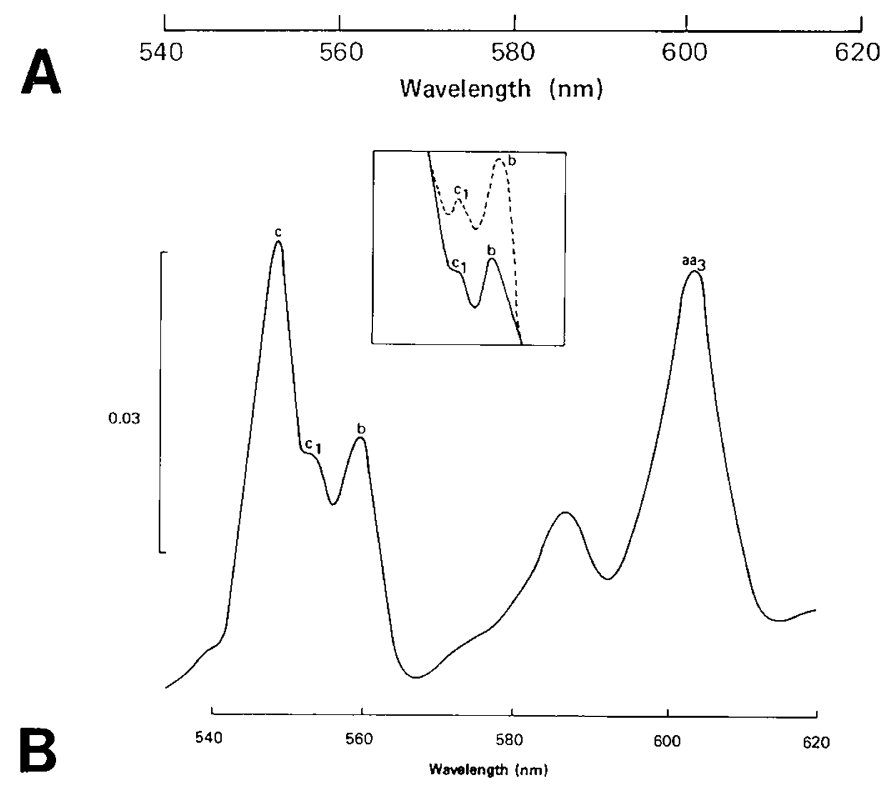

Fig. 1. Reduced minus oxidized difference spectrum of skeletal muscle mitochondrial fraction from the patient and a control. The spectra were recorded at $-190^{\circ} \mathrm{C}$. The sample cells were reduced with $10-\mathrm{mM}$ succinate and $0.1-\mathrm{mM} \mathrm{KCN}$. Inserts shows that further reduction with dithionite causes increased absorbance by cytochrome $\mathrm{b}$ with a peak shift from $562 \mathrm{~nm}$ to $566 \mathrm{~nm}$ (same scale, dotted line after dithionite). A, the spectra from the patient's mitochondria; each cell contained $1.8 \mathrm{mg}$ mitochondrial protein. $B$, shows spectra from control mitochondria; each cell contained $1.5 \mathrm{mg}$ mitochondrial protein. Very similar spectra to those shown in $A$ were obtained with heart mitochondria from the patient.

Table 1. Rates of substrate oxidations by mitochondrial fractions*

\begin{tabular}{llrr}
\hline \multicolumn{1}{c}{ Tissue } & \multicolumn{1}{c}{ Substrate } & Controls & Patient A.S. \\
\hline Skeletal muscle & 10 -mM-succinate & $234 \pm 20(12)$ & 48 \\
& 10 -mM-glutamate + 1-mM-malate & $88 \pm 20(12)$ & 26 \\
Heart & 10 -mM-succinate & & 226 \\
& 10 -mM-glutamate + 1-mM-malate & $329 \pm 13(5)$ & 48 \\
Liver & 10 -mM-succinate & $126 \pm 29(5)$ & 88 \\
& 10 -mM-glutamate + 1-mM-malate & & 21 \\
Kidney & 10 -mM-succinate & & 164 \\
& 10 -mM-glutamate + 1-mM-malate & & 36 \\
\hline
\end{tabular}

* Rates are expressed as nmols of ferricyanide reduced (in the presence of $10-\mathrm{mM}-\mathrm{ADP}$ ) $\mathrm{min}^{-1} \cdot \mathrm{mg}$ protein ${ }^{-1}$ as means $\pm \mathrm{SD}$, with the number of observations in parentheses, or as individual values. 
Table 2. Cytochrome concentrations in mitochondrial fractions from skeletal muscle and cardiac muscle*

\begin{tabular}{|c|c|c|c|c|}
\hline & \multicolumn{2}{|c|}{ Controls } & \multicolumn{2}{|c|}{ Patient A.S. } \\
\hline & Succinate & Dithionite & Succinate & Dithionite \\
\hline \multicolumn{5}{|l|}{ Skeletal muscle } \\
\hline Cytochrome $a a_{3}$ & $0.26 \pm 0.10$ & $0.27 \pm 0.06$ & 0.14 & 0.13 \\
\hline Cytochrome $b$ & $0.16 \pm 0.06$ & $0.25 \pm 0.04$ & 0.04 & 0.08 \\
\hline Cytochrome $c$ & $0.22 \pm 0.10$ & $0.28 \pm 0.06$ & 0.14 & 0.16 \\
\hline Cytochrome $a a_{3} /$ cytochrome $c$ & $1.14 \pm 0.14$ & $0.97 \pm 0.13$ & 1.00 & 0.82 \\
\hline Cytochrome $b /$ cytochrome $c$ & $0.68 \pm 0.11$ & $0.92 \pm 0.18$ & 0.27 & 0.50 \\
\hline $\begin{array}{l}\text { Cytochrome } b / \text { cytochrome } \\
a a_{3}\end{array}$ & $0.62 \pm 0.08$ & $0.92 \pm 0.14$ & 0.27 & 0.62 \\
\hline \multicolumn{5}{|l|}{ Cardiac muscle } \\
\hline Cytochrome $a a_{3}$ & 0.40 & 0.37 & 0.21 & 0.29 \\
\hline Cytochrome $b$ & 0.22 & 0.31 & 0.04 & 0.07 \\
\hline Cytochrome $c$ & 0.44 & 0.48 & 0.22 & 0.28 \\
\hline Cytochrome $a a_{3} /$ cytochrome $c$ & 0.91 & 0.76 & 1.00 & 1.02 \\
\hline Cytochrome $b /$ cytochrome $c$ & 0.45 & 0.63 & 0.16 & 0.35 \\
\hline Cytochrome $b /$ cytochrome & 0.54 & 0.83 & 0.17 & 0.34 \\
\hline
\end{tabular}

* Cytochrome concentrations were determined from low temperature redox spectra with succinate or dithionite as reductants. The results are expressed as nmol $\mathrm{mg}_{\text {protein }}{ }^{-1}$ and are mean $\pm \mathrm{SD}$ for eight controls or individual values. The concentration of cytochrome $a$ is expressed as $a+$ $a_{3}$; however, as cytochrome $c$ oxidase contains both heme groups in one complex, the concentration of cytochrome $c$ oxidase is one-half that of cytochrome $a a_{3}$ reported above (37). The values are expressed as cytochrome $a a_{3}$ to allow comparison with results from other investigators.

Table 3. Activities of individual respiratory chain complexes and determination of duroquinol-ubiquinone transhydrogenase activity*

\begin{tabular}{|c|c|c|c|c|c|c|}
\hline & \multicolumn{2}{|c|}{ Skeletal muscle } & \multicolumn{2}{|c|}{ Cardiac muscle } & \multicolumn{2}{|c|}{ Liver } \\
\hline & Controls & Patient A.S. & Controls & Patient A.S. & Controls & Patient A.S. \\
\hline \multicolumn{7}{|c|}{ Respiratory chain complexes } \\
\hline Complex I & $40 \pm 14$ & 30 & 62,36 & 48 & $20 \pm 5$ & 15 \\
\hline Complex II & $35 \pm 3$ & 31 & 45,49 & 25 & $47 \pm 7$ & 35 \\
\hline Complex III & $0.69 \pm 0.06$ & 0.26 & $0.81,0.94$ & 0.49 & $0.13 \pm 0.02$ & 0.05 \\
\hline Complex IV & $0.67 \pm 0.04$ & 0.33 & $0.53,0.69$ & 0.59 & $0.13 \pm 0.02$ & 0.14 \\
\hline \multicolumn{7}{|c|}{ Duroquinol-ubiquinone } \\
\hline + Antimycin & $0.11,0.11$ & 0.09 & 0.11 & 0.09 & 0.06 & 0.05 \\
\hline - Antimycin & $0.22,0.24$ & 0.11 & 0.27 & 0.14 & 0.10 & 0.05 \\
\hline
\end{tabular}

* The activities of the complexes were measured at $30^{\circ} \mathrm{C}$ as described in "Materials and Methods" and are expressed as nmol substrate transformed $\mathrm{min}^{-1} \cdot \mathrm{mg}$ mitochondrial protein ${ }^{-1}$ (complexes I and II) or as first order rate constants $\left(\mathrm{s}^{-1} \mathrm{mg}\right.$ protein $^{-1}$ ) (complexes III and IV; duroquinolubiqunone transhydrogenase). The figures shown are the mean $\pm \mathrm{SD}$ or individual values.

about $50 \%$ of controls (Table 2). This contrasts with cytochrome $c_{1}$, which, although difficult to estimate because of the large overlapping peak of cytochrome $c$, appears normal relative to cytochrome $c$ and to cytochrome $a a_{3}$. The recovery of mitochondria from skeletal muscle was similar to that from controls (not shown).

Activities of individual complexes. The activities of complexes I and II were normal in liver and muscle mitochondrial fractions from the patient compared with the controls (Table 3), but the activity of complex III was low in both tissues ( $38 \%$ of controls). Complex III activity was also low in the patient's cardiac mitochondria, but no adequate control data are available for the kidney mitochondrial fraction. The activity of cytochrome $c$ oxidase in the skeletal muscle mitochondrial fraction from our patient was about $50 \%$ of the control values. The concentration of cytochrome $a a_{3}$ determined spectroscopically is also $50 \%$ of controls; however, the ratio of cytochrome $a a_{3}$ to cytochrome $c$ is normal (Table 2). Immunoblotting with antibodies to holocytochrome $c$ oxidase indicated that the relative amounts of the cytochrome $c$ oxidase subunits were normal (not shown). This suggests that the low activity of complex IV in skeletal muscle may be accounted for by the lack of heme rather than the absence of one of the subunits.

Duroquinol-ubiquinone transhydrogenase activity. There was no significant antimycin-sensitive activity in skeletal muscle and liver mitochondria from the patient. In heart mitochondria, the apparent rate constant was about $30 \%$ of control (Table 3 ).

Immunoblot analysis of subunits of complex III. The skeletal muscle, liver and heart mitochondrial fractions from the patient were immunoblotted using antibodies to the $\mathrm{nFeS}$ peptide (Fig. 2), the core proteins (Fig. 3) and holocomplex III (Fig. 4). Mitochondrial fractions from muscle, liver, and heart had markedly lower amounts of the nFeS peptide (Fig. 2). Antibody to the holoenzyme only reacted well with muscle mitochondria and showed the apparently normal amounts of the core proteins, cytochrome $c_{l}$, and subunit VI. In addition, antibody to the core proteins showed a normal amount of these proteins in liver and heart mitochondrial fractions.

\section{DISCUSSION}

Patients previously described with complex III deficiency have presented with a variety of symptoms. In some patients, the defect is apparently confined to skeletal muscle; in others it is generalized. In the former group, exercise-related problems predominate, including muscle discomfort and breathlessness (26). These patients are often weak, and their weakness is exacerbated 


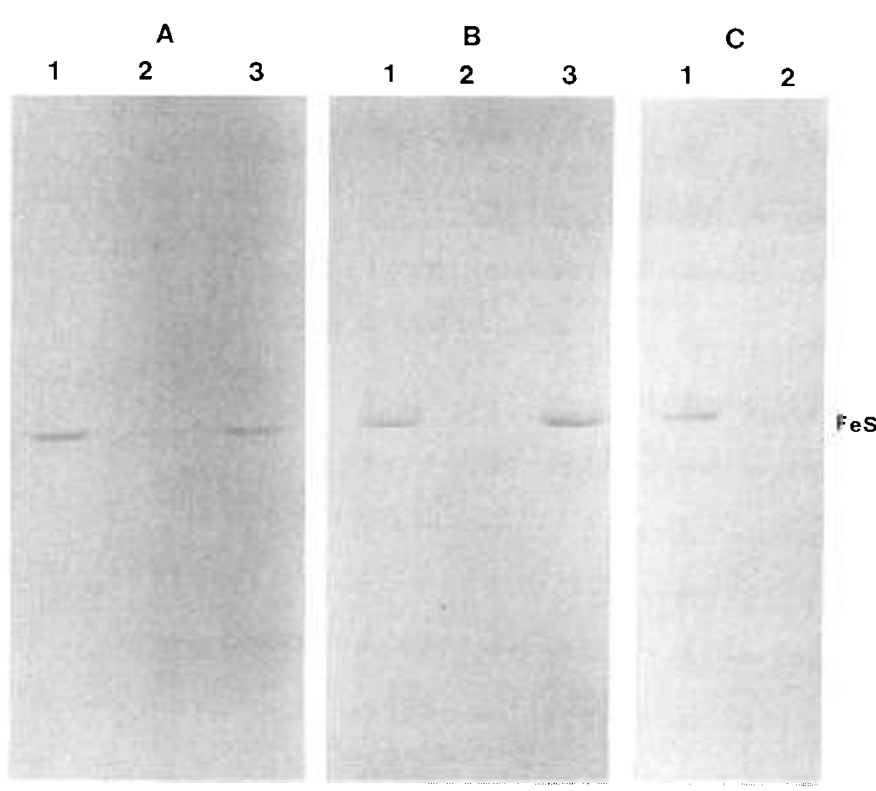

Fig. 2. Immunoblot analysis of $\mathrm{nFeS}$ peptide. Human tissue mitochondrial fractions (75 $\mu \mathrm{g}$ of protein) were loaded on the gel. The separated proteins were subsequently blotted onto nitrocellulose paper which was incubated with antibodies to the nFeS peptide. $A$, human skeletal muscle mitochondria from: lane 1 , adult male; lane 2, patient; lane 3 , adult female. $B$, human liver mitochondrial fractions from: lane 1, 4-mo-old infant; lane 2, patient; lane 3, 13-yr-old girl. $C$, human heart mitochondrial fractions from: lane 1, adult male; lane 2, patient.

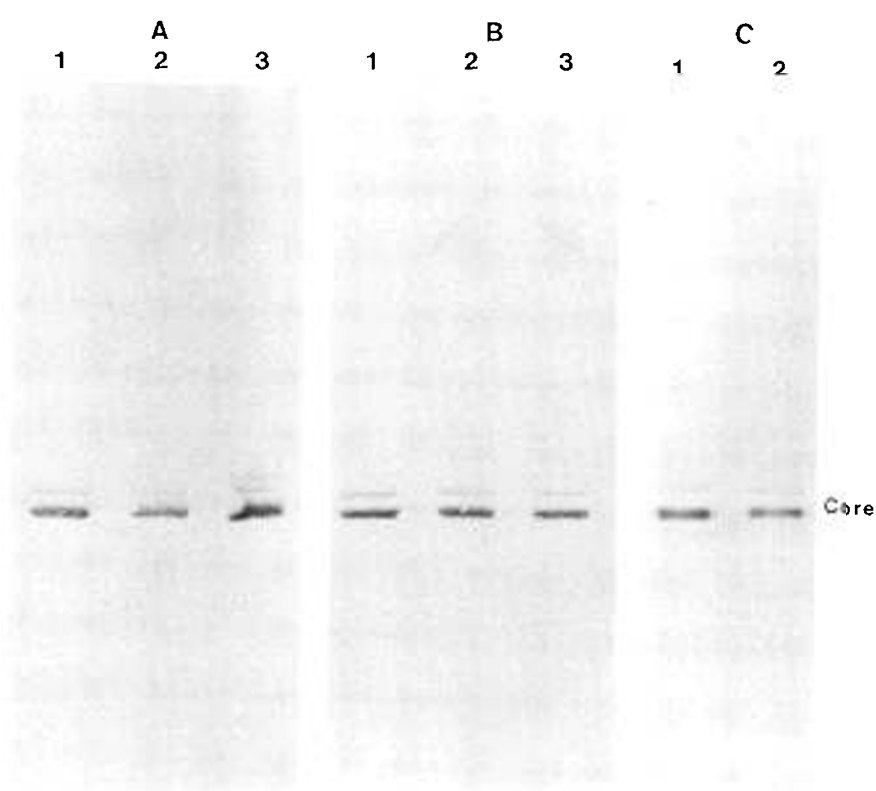

Fig. 3. Immunoblot analysis of the core proteins. $A$, human skeletal muscle mitochondrial fractions (15 $\mu \mathrm{g}$ of protein) from: lane 1 , adult male; lane 2, patient; lane 3 , adult female. $B$, human liver mitochondrial fractions (25 $\mu \mathrm{g}$ of protein) from: lane 1, 4-mo-old infant; lane 2, patient; lane 3, 13-yr-old girl. $C$, human heart mitochondrial fractions $(25 \mu \mathrm{g}$ of protein) from: lane 1 , adult male; lane 2 , patient.

by exertion. Patients with multisystem involvement have presented in their teens or in adult life with muscle weakness, intellectual impairment, ataxia and chorioretinitis $(27,28)$. The presentation of our patient with fatal lactic acidosis in infancy was very different.

The most striking biochemical feature in this patient was the very high blood lactate concentration. Marked lacticacidemia has previously been described in a variety of metabolic conditions

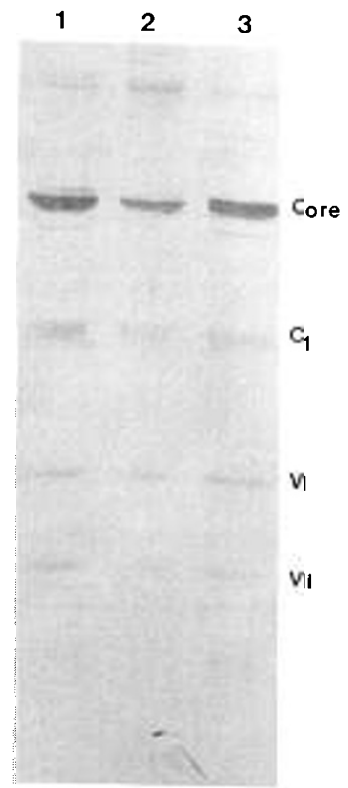

Fig. 4. Immunoblot analysis of holo-complex III. Skeletal muscle mitochondrial fractions ( $100 \mu \mathrm{g}$ of protein) from: lane 1, adult male; lane 2, patient; lane 3 , adult female.

including deficiency of the pyruvate dehydrogenase complex (29), pyruvate carboxylase (30), biotinidase (31), holocarboxylase synthetase (32), fructose-1,6-bisphosphatase (33), glucose-6phosphatase (34), and cytochrome $c$ oxidase (35). None of these possibilities would explain the impaired oxidations of succinate and glutamate in the liver and muscle mitochondria using ferricyanide as an electron acceptor.

Although complex IV was low compared with controls as determined both by direct enzyme assay and spectrophotometrically, the relative amount was normal. However, not only was the absolute amount of complex III low compared with controls, but the there was a proportionally low amount of cytochrome $b$ relative to cytochrome $c$ and cytochrome $a a_{3}$. These results led us to assume that a generalized defect specific to complex III in this patient would explain the metabolic disturbances found. The fact that these were more severe than has been reported previously may have been due either to the impaired energy supply due to the respiratory chain lesion or to the secondary hyperlacticacidemia.

Impaired electron transport would inhibit pyruvate oxidation by decreasing the mitochondrial $\mathrm{NAD}^{+} / \mathrm{NADH}$ ratio. The anaerobic oxidation of pyruvate produces lactate, which is exported into the blood and normally cleared by the liver where it is used as a gluconeogenic precursor. Impaired gluconeogenesis associated with impaired fatty acid oxidation secondary to the respiratory chain disorder (36) would account for the hypoglycemia and lacticacidemia observed in this child.

Previous diagnoses of patients with complex III deficiency have been based on slow rates of oxygen uptake or of succinatecytochrome $c$ (III) reductase and rotenone sensitive NADH-cytochrome $c$ (III) reductase activities in mitochondrial fractions prepared from muscle $(27,37,38)$ or heart (39). In our case, the oxidation of both succinate and $\mathrm{NAD}^{+}$-linked substrates was low in liver and muscle mitochondrial fractions (Table 1). This could be explained by a defect of complex III or a combined defect of complexes I and II. Direct assay showed the defect to be of complex III (Table 4). Further confirmation was provided by the duroquinol-ubiquinone transhydrogenase assay which measures the reactivity of the $b_{\mathrm{i}}$ site of complex III. This activity was low in heart and undetectable in skeletal muscle and liver mitochondria (Table 3).

Immunochemical and spectroscopic studies of complex III demonstrated that there were small amounts of the nFeS peptide 
and of cytochrome $b$ compared with controls. However there were normal amounts of core proteins, cytochrome $c_{1}$, and subunit VI. Antibodies were not available to the other subunits of complex III, so it could not be established whether any other subunits were deficient. In another patient with complex III deficiency, Darley-Usmar et al. (22) found very low amounts of the core proteins, nFeS protein, and subunit VI but a normal amount of cytochrome $c_{1}$, and there are several reports of low amounts of cytochrome $b(27,28,39,40)$.

The child's death from severe acidosis was secondary to a defect in complex III of the respiratory chain, characterized by a partial deficiency of cytochrome $b$ and nFeS. Ten of the 11 peptides including $\mathrm{nFeS}$, are coded for by nuclear DNA, and the cytochrome $b$ apoprotein is coded for by the mitochondrial DNA. The defect, if genetically determined, could be caused by an abnormality of the nuclear or mitochondrial DNA, and two broad possibilities may be outlined.

First, a mutation affecting one of the nuclear-coded subunits could cause impaired incorporation of cytochrome $b$ into an abnormal complex or decreased stability of the complex. However, there are differences in the expression of the defect between skeletal muscle, liver, and heart. The ADP/O ratio was normal in heart and kidney, and the duroquinol-ubiquinol transhydrogenase was less affected in heart than in muscle and liver. This could be caused by mutations of tissue-specific isoforms of one or more of the nuclear-coded subunits of complex III. Possibly a mutation of a single intron causing differently spliced mRNAs might generate different abnormal forms of that subunit in different tissues to account for the range of phenotypic variation observed (41). There are tissue-specific isoforms of nuclear coded, but not mitochondrially coded, subunits of complex IV (42). Alternatively, two isoforms of a single subunit may be expressed in heart, giving a mixed population of complex III oligomers (either in the same or different mitochondria). If only the affected isoform was expressed in liver and skeletal muscle, then these tissues would be more severely affected.

Second, the defect might be caused by a mutation of the mitochondrial DNA. Such defects have recently been described in some mitochondrial myopathies associated with complex I, with heteroplasmy of normal and abnormal DNA in skeletal muscle (43). A mutation in the mitochondrial DNA affecting the cytochrome $b$ apoprotein may have segregated preferentially during early embryogenesis into muscle and liver rather than heart. Tissue-specific differences in expression may have been modified by a background of different isoforms of the nuclearcoded subunits.

Acknowledgments. We would like to thank Dr. Janet Eyre for her help in the management of this patient and Dr. I. C. West, Glynn Research Institute, Bodmin, Cornwall, for helpful discussions.

\section{REFERENCES}

1. Robinson BH, Taylor J, Sherwood WG 1980 The genetic heterogeneity of lactic acidosis: occurence of recognizable inborn errors of metabolism in a pediatric population with lactic acidosis. Pediatr Res 14:956-962

2. DiMauro S, Bonilla E, Zeviani M, Nakagawa M, DeVivo DC 1985 Mitochondrial myopathies. Ann Neurol 17:521-538

3. Hatefi Y 1985 The mitochondrial electron transport and oxidative phosphorylation system. Annu Rev Biochem 54:1015-1069

4. Schägger H, Borchart U, Aquila H, Link TA, vonJagow G 1985 Isolation and amino acid sequence of the smallest subunit of beef heart $b c_{1}$ complex. FEBS Lett 190:89-94

5. Van Biervliet JPGM, Bruinvis L, Ketting D, De Bree PK, Van de Heiden C, Wadman SK, Willems JL, Bookelman H, Van Haelst U, Monnens LAH 1978 Hereditary mitochondrial myopathy with lacticacidemia, a DeToniFanconi-Debre syndrome, and a defective respiratory chain in voluntary striated muscles. Pediatric Res 11:1088 1093

6. Johnson MA 1983 Skeletal muscle. In: Filipe MI, Lake BD (eds) Histochemistry in Pathology. Churchill-Livingstone, London, pp 89-113

7. Seligman AM, Karnovsky MJ, Wasserkrug HL, Hanker JS 1968 Nondroplet ultrastructural demonstration of cytochrome oxidase activity with a polymerizing osmiophillic reagent, diaminobenzidine (DAB). J Cell Biol 38:114

8. Watmough NJ, Bhuiyan AKJM, Bartlett K, Sherratt HSA, Turnbull DM 1988 Skeletal muscle mitochondrial $\beta$-oxidation. A study of the products of oxidation of $\left[\mathrm{U}-{ }^{14} \mathrm{C}\right]$ hexadecanoate by h.p.l.c. using continuous on-line radiochemical detection. Biochem J 253:541-547

9. Gatley SJ, Sherratt HSA 1976 The effects of diphenyleneiodonium on mito chondrial reactions. Biochem J 158:307-315

10. Sherratt HSA, Watmough NJ, Johnson MA, Turnbull DM 1988 Methods for the study of normal and abnormal skeletal muscle mitochondria. Methods Biochem Anal 33:243-335

11. Turnbull DM, Sherratt HSA, Davies DM, Sykes AG 1982 Tetracyano-2,2bipyridineiron (III), an improved electron acceptor for the spectrophotometric assay of $\beta$-oxidation and succinate dehydrogenase in intact mitochondria. Biochem J 206:511-516

12. Bookelman H, Trijbels JMF, Sengers RCA, Janssen AJM 1978 Measurement of cytochromes in human skeletal muscle, isolated from fresh frozen stored muscle specimens. Biochem Med 19:366-373

13. Wilson DF 1967 Effect of temperature on the spectral properties of some ferrocytochromes. Arch Biochem Biophys 121:757-768

14. Fischer JC 1985 Mitochondrial myopathies and respiratory chain defects Doctoral Thesis, University of Nijmegen, Nijmegen, The Netherlands

15. Sottocasa GL, Kuylenstierna B, Ernster L, Bergstrand A 1967 An electron transport system associated with the outer-membrane of liver mitochondria: a biochemical and morphological study. J Cell Biol 32:415-438

16. Lenaz G, Esposti MD, Fato R, Cabrini L 1981 Studies on coenzyme Q enzymes: role of the isoprenoid chain in the function of ubiquinone. In Folker K, Yamamura Y (eds) Biomedical and Clinical Aspects of Coenzyme Q, vol 3. Elsvier/Biomedical Press, Amsterdam, pp 169-182

17. Nelson BD, Gellerfors P 1978 Characterisation and resolution of complex III from beef heart mitochondria. Methods Enzymol 53:80-91

18. Smith L 1955 Spectrophotometric assay of cytochrome $\mathrm{c}$ oxidase. Methods Biochem Anal 2:427-434

19. Boveris A, Oshino R, Erecinska N, Chance B 1971 Reduction of mitochondria components by durohydroquinone. Biochim Biophys Acta 245:1-16

20. Von Jagow G, Ljungdahl PO, Graf P, Ohnishi T, Trumpower BL 1984 An inhibitor of mitochondrial respiration which binds to cytochrome $b$ and displaces quinone from the iron-sulphur protein of the cytochrome $b c_{1}$ complex. J Biol Chem 259:6318-6326

21. Fuller SD, Darley-Usmar VM, Capaldi RA 1981 Covalent complex between yeast cytochrome $\mathrm{c}$ and beef heart cytochrome $\mathrm{c}$ oxidase which is active in electron transfer. Biochemistry 20:7046-7053

22. Darley-Usmar VM, Kennaway NG, Buist NRM, Capaldi RA 1983 Deficiency in ubiquinone-cytochrome $\mathrm{c}$ reductase in a patient with mitochondrial myopathy and lactic acidosis. Proc Natl Acad Sci USA 80:5103-5106

23. Towbin H, Staehelin T, Gordon J 1979 Electrophoretic transfer of proteins from polyacrylamide gels to nitrocellulose sheets: procedure and some applications. Proc Natl Acad Sci USA 76:4350-4354

24. Domin BA, Serabjit-Singh CJ, Philpot RM 1984 Quantitation of rabbit cytochrome $\mathrm{p}-450$, form 2 , in microsomal preparation bound directly to nitrocellulose paper using a modified peroxidase-immunostaining technique. Anal Biochem 136:390-396

25. Turnbull DM, Johnson MA, Dick DJ, Cartlidge NEF, Sherratt HSA 1985 Partial cytochrome c oxidase deficiency without subsarcolemmal accumulation of mitochondria in chronic progressive external ophthalmoplegia. $J$ Neurol Sci 70:93-100

26. Petty RKH, Harding AE, Morgan-Hughes JA 1986 The clinical features of mitochondrial myopathy. Brain 109:915-938

27. Morgan-Hughes JA, Hayes DJ, Clark JB, Landon DN, Swash M, Stark RJ, Rudge P 1982 Mitochondrial encephalomyopathies: biochemical studies in two cases revealing defects in the respiratory chain. Brain 105:553-582

28. Spiro AJ, Moore CL, Prineas JW, Strasberg PM, Rapin I 1970 A cytochrome related disorder of the nervous system and muscle. Arch Neurol 23:103-112

29. Kerr DS, Ho L, Berlin CM, LaNoue KF, Towfighi J, Hoppel CL, Lusk MM Gondek CM, Patel MS 1987 Systemic deficiency of the first component of the pyruvate dehydrogenase complex. Pediatr Res 22:312-318

30. Bartlett K, Ghniem HK, Stirk JH, Dale G, Alberti KGMM 1984 Pyruvate Carboxylase Deficiency. J Inherited Metab Dis 7(suppl 1):74-78

31. Wastell HJ, Bartlett K, Dale G, Sheir SH 1988 Biotinidase deficiency: a survey of 10 cases. Arch Dis Child 63:1244-1249

32. Bartlett K, Ghniem HK, Stirk JH, Wastell HJ, Sherratt HSA, Leonard JV 1985 Enzyme studies in combined carboxylase deficiency. Ann NY Acad Sci 447:235-251

33. Baerlocher K, Gitzelmann R, Steinmann B 1979 Clinical and genetic studies of disorders in fructose metabolism. In: Burmann D, Holton, JB (eds) Inherited Disorders of Carbohydrate Metabolism, MTP Press, Lancaster, U.K. pp 163-190

34. Mason HH, Anderson DH 1955 Glycogen disease of the liver (Von Geirke's disease) with hepatoma. Pediatrics 16:785-800

35. DiMauro S, Servidei S, Zeviani M, DiRocco M, Devivo DC, DiDonato S, Uziel G, Berry K, Hoganson G, Johnsen SD, Johnson PC 1987 Cytochrome c oxidase deficiency in Leigh's Syndrome. Ann Neurol 22:498-506

36. Sherratt HSA 1981 The inhibition of gluconeogenesis by non-hormonal hypoglyceamic compounds. In: Hue L, Van de Werve G (eds) Short Term Regulation of Liver Metabolism. Elsevier/Biomedical Press, Amsterdam, pp 199-222

37. Kennaway NG, Buist NRM, Darley-Usmar VM, Papadimitriou A, DiMauro 
S, Kelly RI, Capaldi RA, Blank NK, d'Agostino A 1984 Lactic acidosis and mitochondrial myopathy associated with deficiency of several components of complex III of the respiratory chain. Pediatr Res 18:991-999

38. Reichmann H, Rohkamm R, Zeviani M, Servidei S, Ricker K, DiMauro S 1986 Mitochondrial myopathy due to complex III deficiency with normal reducible cytochrome b concentration. Arch Neurol 43:957-961

39. Papadimitriou A, Neustein BN, DiMauro S, Stanton R, Bresolin N 1984 Histiocytoid cardiomyopathy of infancy: deficiency of reducible cytochrome b activity in heart mitochondria. Pediatr Res 18:1023-1028

40. Morgan-Hughes JA, Darveniza P, Kahn SN, Landon DN, Sherratt RM, Land
JM, Clark JB 1977 A mitochondrial myopathy characterised by a deficiency in reducible cytochrome b. Brain 100:617-640

41. Breitbart RE, Andreadis A, Nadal-Ginard B 1987 Alternative splicing: a ubiquitous mechanism for the generation of multiple protein isoforms from single genes. Annu Rev Biochem 56:467-498

42. Kadenbach B, Merle P 1981 The function of multiple subunits of cytochrome $c$ oxicase from higher eukaryotes. FEBS Lett $135: 1-11$

43. Holt IJ, Harding AE, Morgan-Hughes JA 1988 Deletion of muscle mitochondrial DNA in patients with mitochondrial myopathies. Nature 331:717-719. 